\title{
ENTERPRISE RISK MANAGEMENT IMPLEMENTATION: A REVIEW OF GOOD PRACTICE
}

\author{
Adina-Liliana Prioteasa ${ }^{272}$ \\ Vasile-Emil Stefan ${ }^{273}$ \\ Carmen Nadia Ciocoiu ${ }^{274}$
}

https://doi.org/10.31410/itema.2018.749

\begin{abstract}
The inherent complexity and risk profile of business operations and of financial and capital markets in which they operate increase the importance of effective risk management practices and the modalities of their implementation and application. In view of this, it is essential to know the aspects of the implementation of risk management, which is why a review of the literature has been carried out.

After defining the search criteria, the search was performed on the Web of Science Core Collection database, where 4 articles were obtained. To consolidate research, it was considered appropriate to perform a search on Google Search to identify the studies carried out by practitioners. 9 studies were obtained, forming a final 13-articles database.

The main objective of this work is to provide an overview of the existing literature on implementation of risk management within organizations, identifying key issues raised by authors and suggesting possible research pathways in this area.
\end{abstract}

Keywords: enterprise risk management, implementation, good practice, review.

\section{INTRODUCTION}

I $\mathrm{n}$ recent years, risk management has developed into an accepted discipline, assigning its own language, tools and techniques. In the academic environment its proliferation is represented by the growing number of works dealing with this subject but also by the inclusion in the management manuals of sections on risk management [1].

In the business environment, the inherent complexity and risk profile of business operations and the financial and capital markets in which they act, increase the importance of effective risk management practices and the detailed rules of application [2].

The benefits for the organizations through the adoption of risk management practices make its importance widely recognized. The main advantages that strengthen the need for implementation of risk management are represented by: reducing the variability in the performance of the entity, aligning and integrating different opinions related to risk management, improving stakeholders' confidence and involvement, strengthening the relationship between the risk management mechanism and corporate governance, increasing the capacity to successfully respond to the permanent changes in the business environment and the development of an open and positive culture with regard to risk management [3].

\footnotetext{
272 The Bucharest University of Economic Studies, Bucharest, Romania

273 The Bucharest University of Economic Studies, Bucharest, Romania

274 The Bucharest University of Economic Studies, Bucharest, Romania
} 
In practice, the implementation of risk management has provided different advantages to organizations such as: reducing the total cost of risk of the turnover from $2.7 \%$ in 2006 to an estimated 2.2\% in 2010 (DLA Piper), reducing risk exposure by $85 \%$ for 51 analyzed projects (Nestle), financial exposure of significant risks decreased by $70 \%$ (governmental agency) [4].

Implementation of integrated risk management is an exercise in change management, there will be people who embrace change and see it as a welcome improvement for the company, but there will be people who consider change as an unnecessary work [5].

The implementation of the integrated approach to risk management within the organization is a process that is usually carried out over several years and is subject to numerous factors. This is possible in the context of a strong initial strength deriving from the novelty of the initiative, but also of an aspiration to obtain a fully mature programme [6].

As any major project involving a multi-year process, the action plan must be realistic in terms of objectives, sub-objectives and timelines [7], the main objective being the expansion and deepening of the ERM capacities of the organization [8].

Organizations often consider it useful to start the implementation initiative with caution, addressing smaller projects first, so that tangible results can be achieved early. Early successes can help generate momentum, enthusiasm and probably funding for future risk management initiatives [9].

The research is structured as follows: after introduction, research methodology, main results and discussions, conclusions are presented.

\section{RESEARCH METHODOLOGY}

The main objective of this work is to provide an overview of the existing literature on implementation of risk management within organizations, to identify key issues raised by authors and to suggest possible research pathways in this area.

In order to achieve the objectives, a database of 13 articles was built, which was subsequently analyzed to extract issues related to implementation of risk management. The following steps have been carried out in detail:

A. Setting keywords: risk management, implementation.

B. Selecting databases.

It was decided to use the Web of Science Core Collection database due to the fact that the base information are used (search, discovery and evaluation) by nearly 7,000 academic and government institutions and top corporations, it has 1.3 billion references quoted since 1900, complete references containing data related to authors and affiliation and incorporates more than 18000 journals, carefully and objectively selected by quality [10].

The low number of research obtained in the Web of Science Core Collection database has led to an examination on Google Search. In view of the reduced approach of the subject of the implementation of risk management by academics, a review of the bibliography made available by the practitioners was considered appropriate. 
A number of documents have been found dealing with the subject in many respects. It is true that most of them focus on the effective application of risk management, but those that have a conceptual approach to implementing risk management have been identified.

\section{Effective search performance}

In the Web of Science Core Collection database, the Key words were initially introduced: "Risk Management" in "Title" and "Implementation" in "Topic", resulting in 1435 articles. Given the large number of returned results, it was decided to enter the keyword "Enterprise" in the "Title" alongside the other two previously established words. A list of 76 articles was obtained, coming from various fields besides the ones of interest (management, economics, business, business finance) such as: industrial and civil engineering, public administration, telecommunications, computer science information systems, construction building technology etc.

The final search focused on the three key words entered in the title and the database returned 13 articles, published between 2007-2018, most of them from year 2011 (4 articles) and 2014 ( 3 articles). Given the small number of results, the refining by document type and field of origin was waived, directly performing the analysis. Of these, 5 were not available, 4 were not in accordance with the requirements of the research, and therefore, 4 articles of the Web of Science Core Collection are considered the result.

The same keywords were used on Google Search, but two searches were made, the first in May 2018 where they resulted in 4 documents and the second in August 2018 where they resulted in 5 more documents. Most are published after the year 2009, only one is from 2003.

\section{RESULTS AND DISCUSSIONS}

The data collected through the revision of literature has been deeply analyzed to gain insight into the ERM implementation, to identify important aspects and to draw conclusions on the manner in which the literature covers this specific subject. Table 1 summarizes both data relating to authors, the year of publication, the title of the research and, where appropriate, the magazine, conference or publisher and relevant information extracted there from.

Table 1: List of articles used in the revision of literature

\begin{tabular}{|c|c|c|}
\hline $\begin{array}{l}\text { Authors, Year, Title, } \\
\text { Journal }\end{array}$ & $\begin{array}{l}\text { Issues/Topics } \\
\text { covered }\end{array}$ & Description of topics covered \\
\hline \multicolumn{3}{|c|}{ WEB of SCIENCE CORE COLLECTION } \\
\hline $\begin{array}{l}\text { Rostami, A., Sommerville, } \\
\text { J., Wong, I. L., \& Lee, C. } \\
\text { (2015). Risk management } \\
\text { implementation in small and } \\
\text { medium enterprises in the } \\
\text { UK construction industry. } \\
\text { Engineering, Construction } \\
\text { and Architectural } \\
\text { Management, } 22 \text { (1), 91- } \\
107 .\end{array}$ & $\begin{array}{l}\text { Involved } \\
\text { variables in } \\
\text { ERM } \\
\text { implementation }\end{array}$ & $\begin{array}{l}\text { (1) Managerial awareness and/or support } \\
\text { on ERM implementation, (2) financial } \\
\text { resources for technology and training, (3) } \\
\text { the adoption of appropriate tools and } \\
\text { techniques for risk management, (4) } \\
\text { skilled personnel, (5) personal } \\
\text { ownership, (6) developing an appropriate } \\
\text { risk management culture. }\end{array}$ \\
\hline $\begin{array}{l}\text { Ahmad, S., Ng, C., \& } \\
\text { McManus, L.A. (2014). } \\
\text { Enterprise risk management }\end{array}$ & $\begin{array}{l}\text { Aspects of ERM } \\
\text { implementation }\end{array}$ & $\begin{array}{l}\text { (1) ERM implementation is congruent } \\
\text { with investors and other stakeholders' } \\
\text { demands for better corporate governance, }\end{array}$ \\
\hline
\end{tabular}




\begin{tabular}{|c|c|c|}
\hline $\begin{array}{l}\text { (ERM) implementation: } \\
\text { Some empirical evidence } \\
\text { from large Australian } \\
\text { companies. International } \\
\text { Conference On Accounting } \\
\text { Studies 2014, August 18-19, } \\
\text { 2014, Kuala Lumpur: } \\
\text { Procedia Social and } \\
\text { Behavioral Sciences, pp. } \\
\text { 541-547. }\end{array}$ & & $\begin{array}{l}\text { (2) the implementation is considered } \\
\text { complete or full when ERM is embedded } \\
\text { into corporate strategic planning and } \\
\text { decision making processes, (3) a } \\
\text { consistent trend of Chief Risk Officers } \\
\text { (CRO) appointment within firms that } \\
\text { implement ERM, while others use the } \\
\text { existence of a CRO as proxy to ERM } \\
\text { implementation. }\end{array}$ \\
\hline $\begin{array}{l}\text { Zhao, X. B., Hwang, B. G., } \\
\text { Low, S. P. (2014). } \\
\text { Enterprise risk management } \\
\text { implementation in } \\
\text { construction firms: An } \\
\text { organizational change } \\
\text { perspective, Management } \\
\text { Decision, } 52(5), 814-833 .\end{array}$ & $\begin{array}{l}\text { Drivers for } \\
\text { ERM } \\
\text { implementation }\end{array}$ & $\begin{array}{l}\text { (1) compliance and regulatory } \\
\text { requirements, (2) the occurrence of } \\
\text { reports or standards, (3) reducing revenue } \\
\text { volatility, (4) low costs and losses, (5) } \\
\text { increase profitability and earnings, (6) } \\
\text { improving decision-making, } \\
\text { (7) better risk reporting and } \\
\text { communication, (8) better allocation of } \\
\text { resources, (9) improve owner } \\
\text { satisfaction, (10) improving control over } \\
\text { business and ongoing projects, (11) a } \\
\text { wider range of risks, (12) IT advances, } \\
\text { (13) encouragement by management to } \\
\text { such practices. }\end{array}$ \\
\hline $\begin{array}{l}\text { Lai, F. W., Samad, F. A. } \\
\text { (2011). Enterprise risk } \\
\text { management framework and } \\
\text { the empirical determinants } \\
\text { of its implementation. } \\
\text { International Conference on } \\
\text { Business and Economics } \\
\text { Research 2010, November } \\
\text { 26-28, 2010, Kuala Lumpur: } \\
\text { Procedia International } \\
\text { Proceedings of Economics } \\
\text { Development and Research, } \\
\text { pp. 340-344. }\end{array}$ & $\begin{array}{l}\text { Characteristics } \\
\text { of the ERM } \\
\text { implementation } \\
\text { framework }\end{array}$ & $\begin{array}{l}\text { (1) provides common understanding } \\
\text { ERM initiative objectives, (2) provides } \\
\text { common ERM terminology, (3) assures } \\
\text { enterprise-wide information about risk, } \\
\text { (4) enables clear accountability for } \\
\text { human resources involved in risk } \\
\text { management, (5) aligns ERM with } \\
\text { business objectives, strategic planning } \\
\text { and decision making, (6) integrates ERM } \\
\text { with all functions and business units, (9) } \\
\text { provides rigor to risk management } \\
\text { process. }\end{array}$ \\
\hline \multicolumn{3}{|c|}{ GOOGLE SEARCH } \\
\hline $\begin{array}{l}\text { Frigo, M. L., \& Anderson, } \\
\text { R. J. (2011). Embracing } \\
\text { Enterprise Risk } \\
\text { Management: Practical } \\
\text { Approaches for Getting } \\
\text { Started. }\end{array}$ & $\begin{array}{l}\text { Action plan for } \\
\text { ERM } \\
\text { implementation. }\end{array}$ & $\begin{array}{l}\text { 1) seek Board and Senior Management } \\
\text { involvement and oversight, (2) identify } \\
\text { and position a leader to drive the ERM } \\
\text { initiative, (3) establish a management } \\
\text { working group, (4) conduct an initial } \\
\text { enterprise-wide risk assessment and } \\
\text { action plan, (5) inventory the existing risk } \\
\text { management practices, (6) develop initial } \\
\text { risk reporting, (7) develop the next phase } \\
\text { of action plans and ongoing } \\
\text { communications. }\end{array}$ \\
\hline
\end{tabular}




\begin{tabular}{|c|c|c|}
\hline \multirow[t]{2}{*}{$\begin{array}{l}\text { Latilla. (2011). } 8 \text { Step Guide } \\
\text { to Implementing ERM. }\end{array}$} & $\begin{array}{l}\text { Reasons for } \\
\text { ERM } \\
\text { implementation }\end{array}$ & $\begin{array}{l}\text { (1) improved regulator, investor and } \\
\text { rating agency confidence, (2) enhanced } \\
\text { corporate governance, (3) improved } \\
\text { ability to respond to changing business } \\
\text { demands, (4) ability to evaluate the } \\
\text { likelihood and impact of major risks, (5) } \\
\text { provides an integrated as opposed to silo } \\
\text { approach, (6) promotes an open, positive, } \\
\text { risk-aware culture. }\end{array}$ \\
\hline & $\begin{array}{l}\text { Implementation } \\
\text { steps }\end{array}$ & $\begin{array}{l}\text { (1) obtain Board and Senior Management } \\
\text { support and involvement, (2) appoint a } \\
\text { strong ERM leader, (3) establish a risk } \\
\text { committee, (4) conduct a risk assessment, } \\
\text { (5) review existing risk management } \\
\text { practices, augment, controls, implement } \\
\text { action plans, (6) implement risk } \\
\text { reporting, (7) communicate results, (8) } \\
\text { review, enhance, repeat. }\end{array}$ \\
\hline $\begin{array}{l}\text { Protiviti. (2006). Enterprise } \\
\text { Risk Management: Practical } \\
\text { Implementation Advice. }\end{array}$ & $\begin{array}{l}\text { Implementation } \\
\text { steps }\end{array}$ & $\begin{array}{l}\text { 1) conduct an enterprise risk assessment } \\
\text { (ERA), (2) articulate the ERM vision and } \\
\text { value proposition using gaps around the } \\
\text { priority risks, (3) advance the risk } \\
\text { management capabilities of the } \\
\text { organization for one or two priority risks, } \\
\text { (4) evaluate the existing ERM } \\
\text { infrastructure capability and develop a } \\
\text { strategy to advance it, (5) advance the } \\
\text { risk management capabilities for other } \\
\text { key risks. }\end{array}$ \\
\hline \multirow[t]{2}{*}{$\begin{array}{l}\text { The Institution of Civil } \\
\text { Engineers, \& The Faculty } \\
\text { and Institute of Actuaries. } \\
\text { (2009, Iulie). ERM - a guide } \\
\text { to implementation. }\end{array}$} & $\begin{array}{l}\text { Key tasks } \\
\text { preceding } \\
\text { implementation }\end{array}$ & $\begin{array}{l}\text { (1) study existing risk practices, (2) } \\
\text { construct a vision of future risk } \\
\text { management, (3) plan the } \\
\text { implementation and seek authorization, } \\
\text { (4) seek authorization and prepare to get } \\
\text { started. }\end{array}$ \\
\hline & $\begin{array}{l}\text { Elementary } \\
\text { components in } \\
\text { the development } \\
\text { of } \\
\text { implementation } \\
\text { phases }\end{array}$ & $\begin{array}{l}\text { (1) the Board itself, (2) organizational } \\
\text { matters, (3) methods used for managing } \\
\text { risks, (4) reporting systems, (5) risk } \\
\text { Governance, (6) procedures. }\end{array}$ \\
\hline $\begin{array}{l}\text { Miccolis. J. (2003). } \\
\text { Implementing Enterprise } \\
\text { Risk Management: Getting } \\
\text { the Fundamentals Right. }\end{array}$ & $\begin{array}{l}\text { Four key } \\
\text { questions to } \\
\text { determine the } \\
\text { appropriate } \\
\text { implementation } \\
\text { framework }\end{array}$ & $\begin{array}{l}\text { (1) "What are our objectives for ERM?", } \\
\text { (2) "What will be the scope of our ERM } \\
\text { program?", (3) "What kind of } \\
\text { organizational structure around ERM } \\
\text { will work for us?", (4) "What specific } \\
\text { tools will we need to implement ERM?". }\end{array}$ \\
\hline $\begin{array}{l}\text { Insurance Commission of } \\
\text { Western Australia (2016). }\end{array}$ & $\begin{array}{l}\text { Steps in } \\
\text { implementations }\end{array}$ & $\begin{array}{l}\text { (1) support of Senior Management, (2) } \\
\text { development of the risk management } \\
\text { framework,(3) }\end{array}$ \\
\hline
\end{tabular}




\begin{tabular}{|c|c|c|}
\hline $\begin{array}{l}\text { Sample Risk Management } \\
\text { Implementation Strategy. }\end{array}$ & & $\begin{array}{l}\text { communication/education, (4) managing } \\
\text { risks at the strategic level, (5) managing } \\
\text { risks at business unit level: divisional, } \\
\text { program, project and team, } \\
\text { monitoring and review. }\end{array}$ \\
\hline $\begin{array}{l}\text { Brackett. J. (2011), } \\
\text { Enterprise Risk } \\
\text { Management: A pragmatic, } \\
\text { four phase implementation } \\
\text { plan. }\end{array}$ & $\begin{array}{l}\text { A four-phase } \\
\text { ERM } \\
\text { methodology }\end{array}$ & $\begin{array}{l}\text { (1) risk program development, (2) risk } \\
\text { assessment and prioritization, (3) risk } \\
\text { treatment, (4) risk validation and } \\
\text { monitoring. }\end{array}$ \\
\hline $\begin{array}{l}\text { Gallagher Higher Education } \\
\text { Practice (2009). Road to } \\
\text { Implementation: Enterprise } \\
\text { Risk Management for } \\
\text { Colleges and Universities. } \\
\text { Rolling Meadows: Arthur J. } \\
\text { Gallagher \& Co. }\end{array}$ & $\begin{array}{l}\text { ERM } \\
\text { implementation } \\
\text { steps }\end{array}$ & $\begin{array}{l}\text { (1) building a case for ERM, (2) building } \\
\text { an ERM foundation, ( } 3 \text { ) implementation, } \\
\text { (4) sustaining your ERM program. }\end{array}$ \\
\hline \multirow{2}{*}{$\begin{array}{l}\text { Institute of Management } \\
\text { Accountants. (2007). } \\
\text { Enterprise Risk } \\
\text { Management: Tools and } \\
\text { Techniques for Effective } \\
\text { Implementation. }\end{array}$} & $\begin{array}{l}\text { ERM } \\
\text { development } \\
\text { phases }\end{array}$ & $\begin{array}{l}\text { (1) building a foundation, (2) segment } \\
\text { level ERM, (3) enterprise-level ERM. }\end{array}$ \\
\hline & $\begin{array}{l}\text { Practical } \\
\text { implementation } \\
\text { considerations }\end{array}$ & $\begin{array}{l}\text { (1) ERM infrastructure, (2) staging ERM } \\
\text { adoption for early wins, (3) the role of the } \\
\text { management accountant, (4) ERM } \\
\text { educations and training, (4) technology, } \\
\text { (5) aligning corporate culture, (6) } \\
\text { building a case for ERM. }\end{array}$ \\
\hline
\end{tabular}

Following the analysis of the specialized literature, it was found that it addressed the implementation of risk management from the perspective of the steps necessary for the implementation of the ERM, the components of implementation, the factors determining the organizations to such a programme, the characteristics of the ERM framework, but also the benefits provided to organizations through implementation.

The authors' proposals range from general stages of the ERM implementation to some precise ones, focusing mainly on the following pillars: leadership of the organization, organizational aspects, risk management methods, reporting system and procedures [7].

Although many sources consider the support, leadership involvement and the appointment of a leader for the ERM initiative, as the first phases of the implementation process [2], [8], [11], [12], there are also sources that argue and describe the existence of activities that precede those previously stated, activities such as conducting an assessment of existing risk management practices in the organization and building a vision of risk management from the results of the evaluation [7], [13], [14].

Therefore, the first stage is assessment of risk management practices present in the organization. [14] calls this stage "enterprise risk assessment" (ERA), and [8] considers it the center of the implementation process although it positions it after the phases where the management's support is required, the risk leader is appointed, and the composition of the working group is established. 
Conducting such an assessment aims at shaping the current situation of significant risk management capabilities, which will become the starting point and the basis of the development of the ERM vision [14].

Since there is no optimal way of achieving the evaluation, organizations can start by analyzing the business strategy, checking documents containing relevant risk information such as insurance, audit reports and health and environment safety reports [13].

Information can also be obtained by organizing discussions that have the theme of the organization's strategy with the leadership, from where it can result in a list of significant risks for the entity [8], a list that can be improved with risks obtained from organizing interviews, surveys and discussions with other people in the company [2], [12].

The next stage treats the development of a vision of risk management. To develop a vision of how the organization will look with the introduction of the ERM it is necessary to determine the possible benefits but also the necessary changes [13], [7].

Implementation of risk management can give the organization a wide and varied spectrum of advantages, such as: reducing income volatility, lowering costs and losses, increasing profitability and income, improving the decision making process, a good allocation of resources, increased stakeholders satisfaction [15], the common understanding of the objectives and terminology of the ERM, clear responsibilities of human resources involved in risk management, alignment of the ERM with business objectives, integration of ERM with all functions, strengthening the risk management process [16].

The desired risk management status will focus on identifying gaps and setting ways to improve risk management capabilities to close these gaps [12], [14]. Instead, [8] considers that the vision for risk management should not only address the gaps in risk management capacities, but also the solid areas that can be improved.

The greater the gap between the current state and the desired state of the risk management organization's capabilities, the greater is the need to implement the risk management and the duration of development of such capacities [14].

This stage is found in other research in the form of setting goals and purpose, [17] considers that the ERM objectives range from reactive to proactive, being: compliance with regulatory requirements, defense against risks with effects on strategic objectives, coordination and integration of risk management practices in different silos, and for reasons of efficiency and exploitation of opportunities.

The next step is creating an implementation plan. The plan can include an exposure of the need for the ERM implementation, of potential benefits from implementation, examples of good practice, the current situation of capacities and gaps in risk management, necessary human and financial resources, and possible challenges [13]. Further information on the following steps and associated deadlines, the modalities of staff training, possible risks and an estimate of the costs of the implementation can also be included [7].

The implementation plan is handed over to the management and the agreement and support for the implementation of the ERM is required [11]. Once the support is granted, the management should: determine the overall business strategy and objectives, to provide resources, to establish 
target data, to communicate the given support and the importance of risk management and their willingness to increase awareness of risks throughout the company, to give the tonality of the entity's risk culture [12], [18].

Institutionalization of ERM within the company is done either by assigning the responsibilities of the ERM to an existing function, either by setting up a new function, represented by a CRO (Chief Risk Officer), an ERM committee or a working group or a combination of these entities [17].

Appointing a strong leader to lead the implementation of risk management is the next step. The typical qualities of a leader of the ERM include: wide and solid understanding of the business, structure and strategy of the organization, strong working relationships with leadership, knowledge of organization's risks, credibility and respect throughout the company, good project management skills, good communication skills [12], [13].

If such a role (CRO) does not exist in the organization, it is good to use existing resources, for example, the directors of the audit or financial departments, it is not necessary for this person to lead the risk management operation in the long term, but it will lead the initiative [8]. Hiring an outside person in this position can also be considered, someone who will bring a current perspective, new skills and a schedule that is clear and free of other responsibilities [13].

After the nomination of a risk leader, the next stage is forming a workgroup. In comparison to the nomination of a risk leader, the formation of a working group is optional and is used by risk leaders as an effective mean to involve the right people in the organization into the implementation process and to ensure the success of implementation [7].

The committee should also include, besides 'C-suite' directors (Chief Executive Officer - CEO, Chief Financial Officer - CFO, Chief Operating Officer - COO, Chief Information Officer $\mathrm{CIO})$, the main representatives of business units, to ensure that: there is visible top-down support and a bottom-up agreement, risk management efforts are included in the company's core activities, objectives, risks and controls are discussed from several perspectives to increase the degree of awareness and understanding of their impact on the company [12].

The responsibilities of the risk committee include: communication of risk policy, increased awareness on risk management, acquisition and development of risk management skills, elaboration of specific documentation (forms, register of risk), development of a process of performance management and a process of recognition, rewards and sanctions [17].

The next step involves the development and implementation of an action plan aimed at issues such as leadership, culture, education and training, a risk management vocabulary, risk management methods, technology, reporting system and performance indicators system. Figure 1 presents a description of these issues.

The final step of the process is the review and improvement of the ERM programme, given that the completion of the ERM implementation does not mark the completion of the initiative, but the initiation of a continuous process that will become an integral part of the organization structure, strategy planning and decision-making process [15], [19].

Ways to improve the ERM process can consist of: using lessons learnt from the implementation of risk management, regular communications on different types of risks, organizing internal 
trainings on policies and risk practices for new and existing employees and the organization of training courses on risk skills [12].

Figure 1: Description of the action plan elements on implementation of the ERM.

- The ways to improve the involvement of management in the
implementation process may involve the co-opting of a director
outside the company for extending the management experience,
organizing regular meetings on ERM or providing information to
management of the ERM concepts.
- The creation of a risk management culture is the responsibility of
leadership, and its characteristics are: openness, favourable to risk
management, with consultative leadership, participation in decision-
making on risks, organizational learning, knowledge exchange, good
internal communication and cultural changes, such as the shift from
blame to liability, a transition from withholding unfavourable
information to immediate reporting, and shifting from an assessment
of the impact of work on the area or unit to an assessment of the
impact of work on the whole organisation.
- Trainings may include information related to: the nature of the risk,
the legal and regulatory requirements related to risk management, the
existing ERM frameworks, the skills required for risk management,
the process of identification and risk assessment, realization of risk
maps, reporting structures, use of specialized software and
performance measurements.

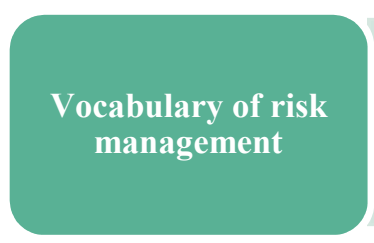

- Developing a common risk vocabulary is a critical point in developing a risk communication and culture, it is designed to establish a common understanding of the terms, concepts and phrases describing the ERM process.

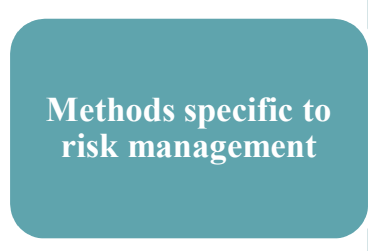

- The improvement of methods used for risk management may include: establishing systems for the development of appropriate risk responses, using a methodical but imaginative and creative approach, establishing systems of monitoring for specific risks for which adequate responses have not been implemented, reviewing and improving the various methods used to manage strategic, project and operational risks.

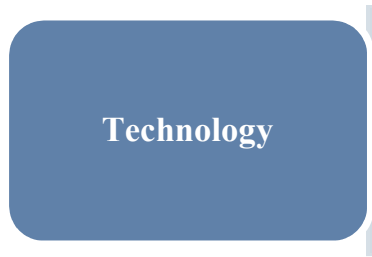

-With regards to the development of risk management software, organizations can use their own resources to create a program tailored to their needs, hire consultants to help develop or purchase the software. These, in addition to assisting the organisation with the entire risk management process, also help to collect, model or report data.

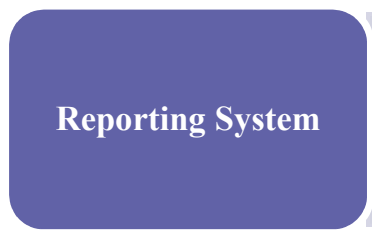

- New reporting formats will be developed (where the graphs and colours can be used on a large scale), the new formats can also include a risk dashboard for leadership and their effectiveness can be tested by stakeholders and subsequently revised.

Performance Indicators System
- The risk committee will develop and apply a system of indicators and a mechanism for the continuous monitoring and review of the risk management process.

Source: adapted from [7], [8], [12], [13], [20] 


\section{CONCLUSIONS}

Implementation of risk management is a recent topic, but interest in the topic is growing both from an academic point of view, by increasing the number of works published on this subject and from the point of view of practitioners who are stimulated to adopt risk management practices.

In academia, the topic of the ERM implementation is treated from the perspective of the process components, the characteristics of the ERM framework, the benefits, the determining factors and the challenges.

Instead, practitioners are channeling their efforts on the actual stages of implementation of risk management in the form of a plan of implementation, phases, steps, methodology, essential elements on the basis of which the implementation steps are determined. The inclination of practitioners to address the actual implementation of the ERM can be attributed either to experience or to the study of the domain for application.

The efforts of the business environment have not gone unnoticed, in 2018, the International Standardization Organization includes in the ISO 31000:2018 Risk Management Standard Guidelines 10 structured activities in 4 components (plan, implement, measure and learn) related to implementation of ERM [21].

The introduction of information related to the implementation of the ERM within the ISO standard 31000:2018, can be the incentive necessary for organizations to study the process and its benefits, can eliminate the state of indecision of organizations when implementing the ERM or may represent the support for them to begin implementation procedures.

The increase in the trend of implementation of the ERM in the business environment can also represent the formation of a homogeneous basis, with the help of which academics undertake studies, where to obtain real and coherent information about the current state of implementation of the ERM, ways to improve techniques and practices, new practices in obtaining the skills needed in implementing and conducting the ERM process, patterns of the implementation process or challenges and risks of the initiative.

\section{ACKNOWLEDGMENT}

This study is conducted in the doctoral studies of the Bucharest University of Economic Studies.

\section{REFERENCES}

[1] Hilson, D. (2016). Risk Management: Best Practice and Future Developments. Retrieved 23 August, 2018, from https://journal.iaccm.com/contracting-excellence-journal/riskmanagement-best-practice-and-future-developments.

[2] Brackett, J. (2011). Enterprise Risk Management: A pragmatic, four phase implementation plan. Retrieved August 20, 2018, from https://nacdonline.org/files/FileDownloads/PDF/McGladrey_ERM_Pragmatic_FourPhas e_Implementation_Plan.pdf.

[3] Protiviti. (2006). Guide to Enterprise Risk Management - Frequently asked questions. Retrieved September 18, 2018, from http://www.ucop.edu/enterprise-riskmanagement/_files/protiviti_faqguide.pdf. 
[4] Howard, P. (2009, Martie). Remaining buoyant. The Treasurer. Retrieved September 18, 2008, from http://www.treasurers.org/ACTmedia/Mar09TTRiskERM38-39.pdf.

[5] Society of Actuaries. (2006, May). Enterprise Risk Management Specialty Guide. Retrieved September 14, 2018, from https://www.soa.org/library/professional-actuarialspecialty-guides/enterprise-risk-management/2005/august/spg0605erm.pdf.

[6] Association of Government Accountants. (2016). 2016 ERM and Internal Controls Forum Summary. Washington: Association of Government Accountants. Retrieved September 22, 2018, from https://www.agacgfm.org/getattachment/Resources/OnlineLibrary/Executive-Reports/ERM_ExecReport_2016-(1).pdf.aspx.

[7] The Institution of Civil Engineers, \& The Faculty and Institute of Actuaries. (2009). ERM - a guide to implementation. Retrieved May 30, 2018, from https:/www.actuaries.org.uk/documents/erm-guide-implementation-draft.

[8] Frigo, M. L., \& Anderson, R. J. (2011). Embracing Enterprise Risk Management: Practical Approaches for Getting Started. Retrieved May 23, 2018, from https://www.coso.org/Documents/Embracing-ERM-Getting-Started.pdf.

[9] CAS. (2003, Mai). Overview on Enterprise Risk Management. Retrieved September 17, 2018, from https://www.casact.org/area/erm/overview.pdf.

[10] Filip, A. (2018, February). WEB OF SCIENCE CORE COLLECTION pentru începători. [Powerpoint Presentation]. Retrieved September 2, 2018, from https://mail.google.com/mail/u/0/\#search/pentru+incepatori/FMfcgxmZSxflNXxZpdHGv HTrWTrbDZtB? projector $=1 \&$ messagePartId $=0.1$.

[11] Insurance Commission of Western Australia. (2016). Sample Risk Management Implementation Strategy. Retrieved August 19, 2018, from https://www.icwa.wa.gov.au/_data/assets/pdf_file/0015/7116/Risk-ManagementImplementation-Strategy-sample.pdf.

[12] Latilla. (2011, Mai). 8 Step Guide to Implementing ERM. Retrieved May 10, 2018, from http://www.latilla.com/uploads/1/2/2/9/12296845/8_reasons_to_implement_erm_may20 11.pdf.

[13] Gallagher Higher Education Practice. (2009). Road to Implementation: Enterprise Risk Management for Colleges and Universities. Rolling Meadows: Arthur J. Gallagher \& Co.

[14] Protiviti. (2006). Enterprise Risk Management: Practical Implementation Advice. 1-3. Retrieved May 3, 2018, from https://www.protiviti.com/UK-en/insights/bulletinv2-i6.

[15] Zhao, X. B., Hwang, B. G., \& Low, S. P. (2014). Enterprise risk management implementation in construction firms: An organizational change perspective. Management Decision, 52 (5), 814-833.

[16] Lai, F. W., \& Samad, F. A. (2011). Enterprise risk management framework and the empirical determinants of its implementation. International Conference on Business and Economics Research 2010 (pp. 340-344). Kuala Lumpur: Procedia International Proceedings of Economics Development and Research.

[17] Miccolis, J. (2003). Implementing Enterprise Risk Management: Getting the Fundamentals Right. Retrieved August 18, 2018, from https://www.irmi.com/articles/expertcommentary/implementing-enterprise-risk-management-getting-the-fundamentals-right.

[18] Rostami, A., Sommerville, J., Wong, I. L., \& Lee, C. (2015). Risk management implementation in small and medium enterprises in the UK construction industry. Engineering Construction and Architectural Management, 22 (1), 91-107.

[19] Ahmad, S., Ng, C., \& McManus, L. A. (2014). Enterprise risk management (ERM) implementation: Some empirical evidence from large Australian companies. International Conference On Accounting Studies 2014 (pp. 541-547). Kuala Lumpur: Procedia Social and Behavioral Sciences . 
[20] Institute of Management Accountants. (2007). Enterprise Risk Management: Tools and Techniques for Effective Implementation. Retrieved August 16, 2018, from https://erm.ncsu.edu/az/erm/i/chan/marticles/documents/IMAToolsTechniquesMay07.pdf

[21] IRM. (2018). A Risk Practitioners Guide to ISO 31000: 2018. Retrieved September 22, 2018, from https://www.theirm.org/media/3513119/IRM-Report-ISO-31000-2018v3.pdf. 